\title{
VALERIU GAFENCU, A PARADIGM OF ASSUMING PRISON AS TIME AND SPACE FOR BECOMING HOLY
}

Florin BOTEZAN*

\begin{abstract}
Valeriu Gafencu, rightly called "the saint of the prisons", is an iconic image of the prisoner to whom the prison became a path to holiness. Arrested and sentenced to 25 years of prison when he was only 20 years old, 11 years later, on February 18, 1952, after a heavy suffering caused by tuberculosis, Valeriu, reaching the measures of holiness, gave his soul into the hands of the Lord in an atmosphere of great grace, felt by all those present. The prison had helped him to overcome the moralist understanding of Christian life that he had before and to begin to live a spiritual life. This happened after he came to see, through the illumination of the Holy Spirit, the sin deep-rooted in his heart and he started to feel himself responsible for all the sins of humanity. Paradoxically, this knowledge of sin did not throw him into despondency but made him live in the highest degree the blessing of the experience of God's love and care and helped him reach holiness, as it is confessed by all those who knew him. The study, based on letters sent by Valeriu Gafencu from prison and the testimonials of those who knew him, aims at following his way from morality to spiritual life and holiness by assuming the prison as time and space of salvation.
\end{abstract}

Keywords: Valeriu Gafencu, prison, morality, spiritual life, holiness

\section{Introduction}

The political changes occurring in Romania in the context of World War II, and especially the instauration of communism made thousands of people, in successive stages, to be sent to prison because of their political convictions, because of real or imaginary accusations. The prison was a 
time of sifting, the cruel regime of detention subjecting the political prisoners to a harsh trial. Some remained faithful to their political beliefs to the end, others fell, but for many, the prison meant - according to the expression of one of the survivors ${ }^{1}$ - the golden baptismal font in which they received the baptism of the love for God and for their nation, the place in which, through terrible trials, they knew God and approached Him. Some reached the very measures of holiness, becoming people in whom "Christ lived, spoke and is speaking to the twentieth century"2 and to us all. And the person who remained in the memory of all who knew him and who imposed himself in the public conscience as "the saint of the prisons" is Valeriu Gafencu. His spiritual journey during the eleven years of prison is a genuine paradigm of the assumation of the prison as time and space for becoming a holy person. We will try to delineate this paradigm with the help of the letters sent from prison by Valeriu to the people he loved, as well as with the help of the testimonials of the people who knew him, first of all, his friend, Ioan Ianolide.

\section{The moral-Christian and national-heroic education}

Valeriu Gafencu ${ }^{3}$ was born in 1921 in Bessarabia, the county of Sângerei. His father had been a member of the National Council, which

${ }^{1}$ Vasile Turtureanu, in Sfântul închisorilor. Mărturii despre Valeriu Gafencu adunate şi adnotate de Monahul Moise (The Saint of the Prisons. Testimonials on Valeriu Gafencu, collected and explained by Monk Moise) - (hereinafter: Sfântul închisorilor), Alba Iulia, Reîntregirea, 2007, p. 56.

2 Ioan IANOLIDE, Intoarcerea la Hristos. Document pentru o lume nouă (The Return to Christ. Document for a New World) - (hereinafter: The Return to Christ), edition by Mănăstirea Diaconeşti, with a foreword by Father Gheorghe Calciu Dumitreasa, Bucureşti, Christiana, 2006, p. 20.

3 For the biography of Gafencu see: Sfântul închisorilor, p. 13-200; Ioan IANOLIDE, Intoarcerea la Hristos, p. 41-252; Martiri pentru Hristos din Romania în perioada regimului comunist (Martyrs for Christ in Romania during the Communist Regime), Bucureşti, Institutul Biblic şi de Misiune al Bisericii Ortodoxe Române, 2007, p. 257 267; Fabian SEICHE, Martiri şi mărturisitori români din secolul XX. Inchisorile comuniste din România (Romanian Martyrs and Confessors in the Twentieth Century. The Communist Prisons in Romania), Făgăraş, Agaton, 2010, p. 230-239; Matei MARIN (ed.), Fericiţi cei prigoniţi. Martiri ai temniţelor româneşti (Blessed are those who are persecuted. Martyrs of Romanian Prisons), Bucureşti, Bonifaciu, 2008, p. 3435 . 
voted in March 1918 for the union of Bessarabia with Romania, and his mother was a simple woman from the countryside, faithful and with a pure heart. He received a Christian and national education, based on morality, first in the family and later in an organization called Cross Brotherhood, whose member he became when he was a high school student in Bălţi.

The Cross Brotherhood ${ }^{4}$, the youth organization of the Legionary Movement was meant to form an elite which was supposed to take charge of the destiny of the Romanian nation, by selecting the best young people and educating them in a moral-Christian and national-heroic direction, having a system and discipline of military inspiration. Many young people, among which Valeriu Gafencu, joined this organization enthusiastically, attracted by the atmosphere of family, love and sobriety there, but also by the knightly aspect: uniforms, engaging songs, military discipline, appeal to sacrifice and heroism. "The principles of legionary education were extraordinary, Father Părintele Arsenie Papacioc recalls. It was an education which engaged you. This took me out of the latent state of a young man who wanted something but did not know exactly what" . They insisted a great deal on the faith in God and on morality, but also on the love for one's country (it is true that sometimes impregnated by accents of heretic phyletism) and on heroism up to sacrifice. However, there was a quite serious theological confusion, the principles of this organization containing elements foreign to the spirit of Orthodoxy, such as the idea of honor and defending it as justification for pride and vengeance. Ioan Ianolide admits: "We were hovering in a certain confusion, as we had been formed in times of oppression, without guidance, without having literature, we only had a sublime ideal, we strove sincerely and with much enthusiasm"6.

The emphasis on morality made many remain at a superficial level of Christian experiences, being blocked in morality, that is, the observance of some rules of behaviour. However, from a spiritual point of view, such a way of living is "uninspiring and insipid", as "morality is only a first step back, a first primitive step of returning to the spiritual

\footnotetext{
${ }^{4}$ See Sfântul închisorilor, p. 19-38.

${ }^{5}$ Sfântul închisorilor, p. 44.

${ }^{6}$ Ioan IANOLIDE, Intoarcerea la Hristos, p. 33.
} 
life" ", and the one who stops there misses the essential. Christianity, the Church is life, spiritual life, the true life, the eternal life, "the new life with Christ and in Christ, led by the Holy Spirit"8. Morality is an important premise for engaging in such a life, but regarded only as a purpose in itself, it becomes an obstacle in the spiritual progress, as it cultivates self-sufficiency and a subtle pride, hiding the impurity of the heart under the correctness of exterior deeds.

Valeriu Gafencu and many of his generation fellows understood all these in prison, through the illumination of the Holy Spirit, in the school of suffering. "There was no other method of study, of training which to offer the possibility of spiritualization, of spiritual interiorization, of intense relation with God as the suffering there did", confesses Father Arsenie Papacioc, referring to the life in prison. God answered the prayer of the enthusiastic youth who, without knowing what they were asking for (Mt. 20, 22), wanted to sacrifice themselves for their nation and allowed them to descend in the hell of the prisons of Antonescu and of communism, as an occasion to penetrate the depths of spiritual life and reach holiness.

When he was only 20, Valeriu Gafencu, who had become one of the best students of the Faculty of Law in Iaşi after graduating high school, was arrested for his affiliation to the Cross Brotherhood and sentenced to 25 years of prison. From a moral point of view, he had nothing to reproach himself:

"As concerns social life, my relationships with the people of the world I lived in, I was always regarded as a very good person, as an example of honest and exemplary conduct. In high school, but especially at the University, where the level of moral life is very low, everyone professors, colleagues and especially my friends saw in me a model of pure life, a kind of new person, who strove to lead a moral, abstinent life with much determination and tenacity. Polite and correct in attitude, elegant in appearance, I was always attributed the highest appreciation. If

\footnotetext{
${ }^{7}$ Hieromonk Rafail NoICA, Taina vieţii duhovniceşti (The Mystery of Spiritual Life), http://www.nistea.com/rafail_raspunsuri.htm (accessed April 24, 2017).

8 Serghei Bulgakov, Ortodoxia (Orthodoxy), transl. by Nicolae Grosu, Bucureşti, Paideia, 1994, p. 7.

${ }^{9}$ Sfântul închisorilor, p. 45.
} 
I happened to enter a conflict with someone, it was only for the truth. Well, if this is true, why was I brought to prison, alone, far from the noise of the world, far from so many temptations?!" (Aiud Penitentiary, January $29,1946)^{10}$.

\section{The separation from the world}

The unjust arrest and sentence to long years of prison represented for Valeriu Gafencu and thousands of other young people a sudden and forced separation from the world.

"I was living a normal life, I was one of the most appreciated students, loved by everyone; I had an unusual thirst for Ideal: a new world, ruled by Love and justice, the perfect harmony. (...) And I arrived in prison. Was I sad then? Was I glad? I couldn't tell. However, I was convinced that the prison would solve for me a great deal of problems through suffering and detachment from the world (Aiud Penitentiary, March 7, 1946)."

Valeriu intuited very well that the detachment from the world and the suffering would help him reach the truth, Christ the Truth, but he did not guess the way to happiness that the Lord was opening in front of him by calling him to live a spiritual life. The writings of the Philokalia insist on the fact that leaving the things of the vain life and withdrawing from the world are important conditions in order to engage in a spiritual life, thus fulfilling the evangelical advice of leaving everything and following Christ (Mk. 10, 21). Monks do this willingly, withdrawing in a monastery, as "denial of nature for the attainment of what is above nature"11. Nevertheless, as Saint John Climacus remarks, even those who come to the monastery unwillingly, forced by certain circumstances can come to

${ }^{10}$ All the letters of Valeriu Gafencu in this study are quoted at the following address https://valeriugafencu.wordpress.com/about/scrisorile-lui-valeriu-gafencu/(accessed April 24, 2017), where they are published in an extended version. In order to identify them, at the end of the quotation we will mention the place and the date when each one was written.

${ }^{11}$ ST. John Climacus, "Scara dumnezeiescului urcuş" (The Ladder of the divine Ascent) - (hereinafter "Scara"), I, 10, in Filocalia (Philokalia), vol. IX, translation, introduction and notes by Father Dumitru Stăniloae, Bucureşti, Institutul Biblic şi de Misiune al Bisericii Ortodoxe Române, 1980, p. 47. 
lead a fruitful spiritual life if they assume the separation form the world as an occasion to approach Christ and free themselves from sins: "I have seen men who had fled into exile meet the emperor by accident when he was on tour, and then join his company, enter his palace, and dine with him. I have seen seed casually fall on the earth and bear plenty of thriving fruit. And I have seen the opposite, too" ${ }^{\prime 2}$.

Being unwillingly separated from the world, Valeriu got to the lavra of Aiud, a prison turned during the period between1942 and 1948 into a real monastery, a school for experiencing the Philokalia way of life, due to the spiritual preoccupations of a group of prisoners whom he joined. This led to the formation of a trend of living in the spirit of the Philokalia in the world of communist prisons ${ }^{13}$.

\section{Imposed and assumed asceticism}

Entering prison meant first of all the confrontation with suffering: the isolation, the cold, the hunger, an asceticism imposed from the exterior, but assumed by Valeriu as an occasion to suffer for truth, for love and justice.

"I had the firm conviction that I was suffering for the truth. This brought a deep peace into my soul. I was on the way to fulfilling the ideal. And, dear mother, I would like you to know that I suffered a lot. During the first winter I used to wake up at night in my sleep and in the loneliness of the cell, cold and hungry, I watched the darkness and I whispered softly, so that only I should hear, but loud enough for God to hear: «Mother, I am cold, I am hungry!» At first it was really hard. But God has always been with me. He has not left me, not even for a single moment. I began to face the sufferings of the body and little by little I began to taste the new joys." (Aiud Penitentiary, March 7, 1946)

The letters sent to the beloved ones after his entering prison reveal to us that Valeriu was content, at peace with himself, thinking of God, but sad, homesick and longing for freedom. As he confessed later, in a wellknown letter dated January 29, 1946, bearing in mind the opinion on his irreproachable moral conduct, he was tormented by the question "Why

${ }^{12}$ St. John Climacus, "Scara”, I, 30-31, p. 54-55.

${ }^{13}$ Sfântul închisorilor, p. 39. 
was I sent to prison?". A question he asked himself not in order to feel sorry for himself, with revolt against the political regime, against the people who had put him into prison unjustly, and, least of all, against God, but trying to understand the situation spiritually, having complete faith in God's protection. Thus, he came to the great existential questions: "What is life? What is man? What is the Truth?". Isolated in a cell, he read a great deal, concentrating on the Holy Scripture, the Paterikon, the Lives of the Saints, the Holy Fathers, the Orthodox Theology ${ }^{14}$. He meditated and prayed a great deal.

Assuming the separation from the world and the forced asceticism as an occasion to find an answer to the fundamental questions of life, being thankful and trusting God opened him to the work of grace, which gradually illuminates the mind. "I am experiencing the beatitude of having understood the highest meaning of Life - the bright path that leads to heaven", he wrote on May 12, 1943. Without Christ, our God, life would be completely vain, having only one purpose: suffering without any hope". Nonetheless, understanding morality as a supreme stage of Christian living and the subtle pride of self-sufficiency remain obstacles in the way of the true knowledge and deepening in the abundance of the spiritual life: "My soul is pure and I can confess that this is the greatest beatitude and measure of my life" he wrote in the same letter.

\section{The visitation of grace and the awareness of sin}

The turning point in the life of Valeriu Gafencu was in June 1943 when, after a long prayer with tears, illuminated by the Holy Spirit, he reached the awareness of sin. Seeing the burden of his sins was an opportunity of deep humbleness which opened his heart so that it should be filled with the grace of the Holy Spirit.

"And all of a sudden ... O! wonder! How great You are, Lord! I saw my soul full of sins; the root of all human sins - I found it in me...Alas! so many sins... And the eyes of my soul, hardened by pride, did not see them. How great God is! Seeing all my sins, I felt the need to cry them out loud, to renounce them! And a deep peace, a sublime wave of light

${ }^{14}$ Ioan IANOLIDE, Intoarcerea la Hristos, p. 43. 
and love flooded my heart!” (Aiud Penitentiary, January 29, 1946)

The illumination of the Holy Spirit experienced by Valeriu is not a metaphor, but a vision of the divine uncreated light, which, shining inside him, first revealed the darkness in him as "only to the extent in which the light of grace opens the understanding of man's heart, through this vision, be it vision in the full sense of the word or a more concealed understanding, but still a sort of vision, only to the extent of this vision can man see the darkness he lies in"15.

"I saw I was a sinner. I shuddered at the sight of my sins, of my weakness. Then I realized that I, who wanted an ideal world with all my heart, I was myself a sinner. Thus, it was me who had to become a pure person, a new person. And I started to fight the evil inside me." (Aiud Penitentiary, March 7, 1946)

Hence Valeriu understood, just like the great ascetics of all times, that the essence of sin does not consist in breaking some moral norms, but in estranging from the eternal divine life for which man was created, that $\sin$ is first committed in the depths of man's spirit, but its consequences affect the wholeness of man and then redound on the entire world ${ }^{16}$. He understood that the struggle with the cosmic evil begins in your heart, that the change of the world in good begins with your repentance, which is nothing else but progress from darkness to light, from death to life.

The visitation of grace brought him the gift of the compunction which is "in the soul no pleasureless pleasure, for God consoles those who are contrite in heart in a secret way"17 - and the experience of "the mourning which causes joy", which the Fathers of the Philokalia mention and which accompanied him the rest of his life.

"I had moments in my life in prison when I cried with unstoppable tears, realising the nothingness of my human nature, the glory of God, the

${ }^{15}$ Hieromonk Rafail Norca, Cultura Duhului (The Culture of the Spirit), Alba Iulia, Reintregirea, 2002, p. 70.

${ }^{16}$ Archim. Sophrony SAKHarov, Cuviosul Siluan Athonitul (Saint Silouan the Athonite), translated from Russian by hieromonk Rafail (Noica), Alba Iulia, Reîntregirea, 2009, p. 35 .

${ }^{17}$ St. John Climacus, “Scara”, VII, 50, p. 178. 
love. In these tears I found the greatest beatitude I have ever felt." (Aiud Penitentiary, April 10, 1945)

\section{Repentance as resurrection of the soul}

From the moment of the visitation of grace, with an acute awareness of sin, Valeriu started to live intensely, with compunction, as longing for the true life, for the personal relationship with Christ. Confessing sins in front of the spiritual father relieved him, but the repentance remained equally intense, the grace of the Holy Spirit helping him to discover existentially that the everflowing source of life is the love for God and for one's fellows. Assuming in a humble way the responsibility for the sins of the whole humanity - seeing his guilt in his lack of love - and wishing to start sacrificing himself out of love for the others, he lived the complete beatitude of encountering Christ in the Holy Spirit.

"Starting with June 1943, when I experienced the first spiritual shudder as a result of the awareness of sin, I realised that as I went deeper in myself I discovered new sins. In the most concealed depth of the heart I found the everflowing source of life, love. I realised I had trampled on this gift. Then I said: «I have done wrong!». In the ground of my sins I had buried everything God had sown most precious in me. Because I trampled on this holy gift, love, I feel responsible for all the sins of my fellows of all times and all places. But I am a happy man, the happiest man! I constantly feel the love of God, His protection and care. I no longer want to live for myself, but to live for love, to contribute to the happiness of all, with God's gift. To save my soul through the salvation of my fellows. Oh! I am so happy! How can man, this small being, experience so much happiness? Man's life is a priceless gift, it is a miracle and I strive to become a child at heart. After thousands of woes I made the most beautiful friendship in my life. All my life we will live for one another, Heavenly King!" (Aiud Penitentiary, November 20, 1945)

In the Holy Spirit he found the answer to all the existential questions that preoccupied him:

"Then, what is Life? Is it a gift of God, given to us, men, in order to purify our soul from sin and prepare, through Christ, to receive the eternal life, the eternal happiness. What is Man? A being created out of God's 
endless love, who was offered happiness and death and was let free to choose. God always urges him to choose happiness, by getting away from sin. (...) What is the Truth?! The Truth is the Word of God, Christ. We have a commandment from God to live in Truth, to get away from sin, to sacrifice everything for Christ, for the Truth. This is the only way to save ourselves, to gain our happiness." (Aiud Penitentiary, January 29, 1946)

Finding the Lord, Valeriu offered himself to Him completely and definitively. He engaged very seriously in the struggle against passions, aiming not just to control his exterior manifestations (deeds, words), but to acquire inner purity. In the loneliness of the cell (when he was in a period of isolation), as well as when he was together with his friends in the so-called group of the mystics - during the years of amelioration of the detention regime (1944-1948) - he dedicated himself to the work of the hesychast prayer through the guarding of the intellect from all exterior thoughts and the constant calling of the name of the Lord. Thus, as the ones around him noticed, the Holy Spirit gradually penetrated his soul, his mind and his life ${ }^{18}$.

"For a long time I have been sensing and fighting the most subtle thoughts that try to enter my soul. I realise that the devil tries to enter my soul in apparently innocent ways. (...) I am looking for humbleness, as it is very useful for compunction. (...) The struggle against selfishness is very hard. I understand that the true man is the one that succeeded in defeating self-love. (...) Only one attitude is proper: a high Christian life of continuous prayer. It means that what you do should be pure - any deed, any thought or word, any relationship, work, rest, everything should be in a state of prayer, of communion with God. The sin was defeated by love". (Aiud Penitentiary, May 28, 1946)

In his spiritual experience and knowledge, Valeriu Gafencu encounters his contemporary, Silouan the Athonite, this great saint through whom Christ speaks to the world today. As a conclusion of his entire experience of life in the Holy Spirit and illuminated by Him, Saint Silouan teaches us that humbleness is essential in spiritual life, as it is the only way in which we can keep the grace ${ }^{19}$. He teaches us that the Lord

${ }^{18}$ Ioan IANOLIDE, Intoarcerea la Hristos, p. 43.

${ }^{19}$ Archim. Sophrony SaKharov, Cuviosul Siluan Athonitul, p. 249. 
sends adversities so that people should become humble and receive the Holy Spirit, and with the Holy Spirit everything is good, hopeful and wonderful. He urges us: "Become humble and you will see that your afflictions will turn into peace" ${ }^{20}$. It is what Valeriu understood, experienced and expressed in the words:

"We pass through life in order to purify our inner side, to renew ourselves in the Spirit of our Lord Jesus Christ - through Love - in order to become worthy of the eternal happiness. All the suffering we endure is for a unique purpose, the purification of the soul, the recognition of our weakness in front of God, the humbleness through which we can find ourselves again, through which we can renew ourselves in the spirit of Love." (Aiud Penitentiary, March 20, 1945)

Saint Silouan writes: "The soul of the humble person is like the sea: cast a stone into the sea, and for a moment it will disturb its serenity, and then sink to the depths" 21 . It is amazing that, when he wants to describe the state of his soul, Valeriu uses the same image:

"I look into my soul. It is a sea of peace. And above the water, a wave slightly trembles and loses itself in the imensity. Temptations which still cannot trouble my peace. I do not allow them to penetrate the depths. I fight them. «And the Spirit of God was borne over the water». How great You are, Lord!" (Galda, 1946-1948).

The period between 1943 and 1948 represented for Valeriu Gafencu a continuous progress in repentance towards the climax of spiritual life. The confirmation of the fact that he was not in a state of delusion is in the application of the certain criterion of truth revealed to us by Saint Silouan - the love for enemies ${ }^{22}$. In his letters Valeriu reveals to us, without ostentation, that he succeeded in loving his enemies:

"I am so pleased! I am experiencing an unusual peace of the soul that Love offers me. I am aware of this divine gift and I am trying to experience it. What can be more beautiful and more sublime than to love your parents, sisters, relatives, all your beloved ones and your enemies! What can be greater than to come to realise that all of God's creation is

\footnotetext{
${ }^{20}$ Ibidem, p. 328.

${ }^{21}$ Ibidem, p. 329.

22 Ibidem, p. 250.
} 
your sister, your mother and your brother?" (Aiud Penitentiary,

November 22, 1945)

His love for all, even for the enemies, effuses in his humble prayer for the world, which is an expression of the spiritual state of the man who, through the work of the Holy Spirit, resembles Christ, the One Who holds the whole mankind in his heart.

"I live on the effusion of some true waves of love, which overwhelm all my being, penetrated by the awareness of my nothingness as person on earth. I kneel in front of the icon, begging for mercy, help and love for me, for all my parents, relatives, friends, benefactors, enemies." (Aiud Penitentiary, February 20, 1945)

His determined engagement on the way of repentance made Valeriu Gafencu distance himself from the legionary deviations from Orthodoxy (murder as a political weapon, revenge, honor etc.) ${ }^{23}$ and lose interest in politics ${ }^{24}$, as he no longer believed in a political solution. His attitude first caused much hostility among the other prisoners, but then, in the fire of the agony expecting them in communist prisons, many ended up admitting that he was right. In a letter addressed to Father Arsenie Boca, for whom he had a special appreciation, Valeriu explained his attitude, showing that the spiritual knowledge he acquired through the suffering in prison made him understand that the only way to the personal resurrection and to the salvation of the nation is the sacrifice made out of love, partaking the sacrifice of Christ.

"Today I thank with all my heart for the suffering and humiliations I had to endure, for they brought me to the awareness of sin and made me understand that the only way leading to the salvation of the Nation is the evangelical Way: Christ. With every small sacrifice of love I experience a great, unique joy. Out of renunciations, I get my contentment and my soul is thirsty for the complete offering to Christ (...). A long time ago I made the decision to live in a pure way, in a Christian spirit. I am happy, because if my physical freedom is limited by human laws, through the walls of the prison, in exchange God gave me the freedom of the soul by experiencing Love - and this freedom is the supreme good I could have

${ }^{23}$ See Ioan IANOLIDE, Intoarcerea la Hristos, p. 43-44; 46; 81.

${ }^{24}$ Sfântul închisorilor, p. 69. 
earned in this world full of vanities (...). Only to the extent in which we serve God, do we contribute to the salvation of the nation, to its spiritual renewal. For there is only one way leading to Resurrection: Golgotha, the willing sacrifice for Love and Truth." 25

The occasion to offer himself completely to Christ, which Valeriu's soul longed for was not slow in coming once the communist repression began.

\section{The confessing holiness}

In the first part of the year 1948, Valeriu Gafencu and all the ones that had been students at the moment of their arrestation were transferred to the prison of Piteşti, where the satanical experiment of re-education was being prepared. When he went to Piteşti he had already reached the measures of 'the perfect man', having the continuous prayer ${ }^{26}$ and confessing Christ constantly through his words and his life, both in front of his oppressors and of the other prisoners.

"Everyone considered him a saint (...) Valeriu was a man who experienced the word of God at a very high level, I would say the level of the saints, of the great fathers and hermits. He did not speak as much as he experienced, because if he had lived as much as he experienced we would not have been able to understand anything. Valeriu was above understanding. His mere presence, his mere appearance - said his cell mates - brought peace of the soul, the peace of the heart and the peace of the mind and made others nurture devotion for him. All the ones that stayed with him in the cell were devoted to him. That is, he called your love for him through his love for you. I have no doubt he is a saint. (...) Wherever he went, the cell became a prayer! (...) He changed our heart, he stifled our enmity towards the guradians, towards Securitate (the communist secret police), that means he turned our heart from revenge or even hatred, towards God and towards love." 27

25 https://www.marturisitorii.ro/2015/02/18/valeriu-gafencu-scrisoare-catre-arsenieboca-multumesc-din-tot-sufletul-pentru-toate-suferintele-si-umilintele-prin-care-mia-fost-dat-sa-trec/ (accessed April 24, 2017)

${ }^{26}$ Ioan IANOLIDE, Intoarcerea la Hristos, p. 75.

27 *** Viața Părintelui Gheorghe Calciu după mărturiile sale și ale altora (The Life of Father Gheorghe Calciu according to his own Testimony and those of others), 
The detention regime became more and more drastic, Valeriu fell seriously ill with tuberculosis, being close to death. Through this illness, God's providence guarded him from the hell of re-education - in December 1949, shortly before the demonic re-education unleashed, he was transferred, first to Văcăreşti and then to the prison sanatorium of Târgu Ocna.

At Târgu Ocna were brought the prisoners who were severely ill with tuberculosis, having a milder regime than other prisons. Here occurred a phenomenon opposite to the one in Pitești, in the sense that here was created a spiritual atmosphere of high Christian experience, of love and sacrifice. When priests arrived, prisoners could receive confession and communion. In this spiritual atmosphere, many converted to faith and many who had been re-educated succeeded in healing their soul $^{28}$. The soul of this spiritual atmosphere was Valeriu Gafencu. "In those years, 1950 and 1951, almost all the prisoners in Târgu Ocna came to the bed where Valeriu was suffering, at least for a few minutes, in order to partake of his thoughts and of the divine grace effused on him" ${ }^{29}$.

Valeriu lived the last two years of his life in Târgu Ocna. Animated by the desire to sacrifice himself out of love, he ceded to the Jewish Protestant pastor Richard Wurmbrand the medicines that could have healed him. More and more exhausted physically, he ascended towards the climax of spiritual life, living intensely the communion of Christ and the joy of confessing Him.

„In those times, Valeriu had reached spiritual maturity. He was serene, powerful in words, controlled in deeds, constant in prayer, intransigent in attitude, full of love, irradiating a mysterious attraction - and all these while keeping to his bed because of a serious and long illness.(...) In the last two years he colud no longer lie on the bed during the day or night, but he sat up leaning on the edge of the bed, his head falling on his chest. (...) His sleep joined wakefulness and he often told us that while we had

Mănăstirea Diaconeşti (ed.), București, Christiana, 2007, p. 43, 46.

${ }^{28}$ See Sfântul închisorilor, p. 123-132.

29 Aurelian GuȚĂ, Un fenomen care se înscrie în sfera cerească a sfințeniei (A Phenomenon inscribed in the Heavenly Sphere of Holiness), http://www.fericiticeiprigoniti.net/valeriu-gafencu/1206-un-fenomen-care-se-inscrie-insfera-cereasca-a-sfinteniei (accessed April 24, 2017). 
the impression he was sleeping, he was actually praying. His prayer continued in his sleep and that gave his face a pleasant brightness which reverberated around him. Nevertheless, Valeriu was a happy man only through a great inner effort and especially through the gift of God, Who was complete and strong in him, fortifying him to master suffering by living in the spirit. Both the prison guards and his friends were impressed by something in Valeriu, but few knew that something was Christ." 30

The Theotokos, for whom Valeriu had a special devoutness, showed herself to him on the night of his last Christmas (1951), telling him: "I am your love! Do not fear. Do not doubt. The triumph will be that of my Son" 31 .

The end of his earthly life came to crown a life of holiness. Knowing in advance the day of his departure from this life, he received confession and communion, took his leave from his suffering mates who came one by one to see him and he departed to the Lord in a great atmosphere of grace, felt by all the ones present.

"It is the happiest day I have lived, recalls Ioan Ianolide, although the dearest man I had alive was dying. But it was him, on that day, who transmitted me the state of inner plenitude that has accompanied me to this day. I think I was in heaven. I think I was near Christ, too, because Christ was present in Valeriu." ${ }^{2}$

\section{Conclusions}

Ever since he was an adolescent, Valeriu Gafencu wanted to become a man of great value, "a man who can play an extraordinary role in history, a man who can bring the greatest contribution to his nation (Aiud Penitentiary, March 7, 1946). God fulfilled his wish, but in a totally different way from what he had in mind. In prison, through suffering he opened himself to the work of the Holy Spirit and through repentance he reached the resurrection of the soul, understanding that the man of great value, the one that plays an extraordinary role in history and brings the greatest contribution to his nation is only the one who reaches the

${ }^{30}$ Ioan IANOLIDE, Intoarcerea la Hristos, p. 75.

${ }^{31}$ Ibidem, p. 180.

${ }^{32}$ Ibidem, p. 251. 
resemblance with Christ, that is holiness.

"I felt, through the burden of the suffering experienced for the resurrection of the soul, the responsibility I have regarding my own soul, those of my family, my relatives, my friends, the whole nation. And the more I ascended on the ladder of the ideal, the smaller and the more sinful I saw myself, and the ideal was higher, accomplished: Christ! And this is how, little by little, the years of adolescence shattered. The veil on my eyes fell through the struggle against sin and in front of me remained alive, serene, the icon of our Lord Jesus Christ!" (Aiud Penitentiary, Christmas 1945)

Valeriu reached the measures of holiness, becoming a symbol of the Christian assumation of prison as time and space of confessing holiness and "through the will of God, he remained present in the world, so that through his prayers and his love he should carry with us the cross of salvation of mankind" 33 .

\section{References:}

1. *** Martiri pentru Hristos din Romania în perioada regimului comunist (Martyrs for Christ in Romania during the Communist Regime), Bucureşti, Institutul Biblic şi de Misiune al Bisericii Ortodoxe Române, 2007.

2. *** Sfântul închisorilor. Mărturii despre Valeriu Gafencu adunate şi adnotate de Monahul Moise (The Saint of the Prisons. Testimonials on Valeriu Gafencu, collected and explained by Monk Moise), Alba Iulia, Reîntregirea, 2007.

3. *** Viața Părintelui Gheorghe Calciu după mărturiile sale și ale altora (The Life of Father Gheorghe Calciu according to his own Testimony and those of others), Mănăstirea Diaconeşti (ed.), București, Christiana, 2007.

4. BulgaKov, Serghei, Ortodoxia (Orthodoxy), transl. by Nicolae Grosu, Bucureşti, Paideia, 1994.

5. GUȚă, Aurelian, Un fenomen care se înscrie în sfera cerească a sfințeniei (A Phenomenon inscribed in the Heavenly Sphere of Holiness), http://www.fericiticeiprigoniti.net/valeriu-gafencu/ 1206-

${ }^{33}$ Ibidem, p. 223. 
un-fenomen-care-se-inscrie-in-sfera-cereasca-a-sfinteniei (accessed April 24, 2017).

6. IANOLIDE, Ioan, Intoarcerea la Hristos. Document pentru o lume nouă nouă (The Return to Christ. Document for a New World), Mănăstirea Diaconeşti (ed.), with a foreword by Father Gheorghe Calciu Dumitreasa, Bucureşti, Christiana, 2006.

7. MARIN, Matei (ed.), Fericiţi cei prigoniţi. Martiri ai temniţelor româneşti (Blessed are those who are persecuted. Martyrs of Romanian Prisons), București, Bonifaciu, 2008

8. NoICA, Rafail, Cultura Duhului (The Culture of the Spirit), Alba Iulia, Reîntregirea, 2002.

9. NoICA, Rafail, Taina vieţii duhovniceşti (The Mystery of Spiritual Life), http://www.nistea.com/rafail_raspunsuri.html (accessed April 24, 2017).

10. Sakharov, Sophrony, Cuviosul Siluan Athonitul (Saint Silouan the Athonite), translated from Russian by hieromonk Rafail (Noica), Alba Iulia, Reîntregirea, 2009, p. 35.

11. SEICHE, Fabian, Martiri şi mărturisitori români din secolul $X X$. Inchisorile comuniste din România (Romanian Martyrs and Confessors in the Twentieth Century. The Communist Prisons in Romania), Făgăraş, Agaton, 2010.

12. ST. John Climacus, "Scara dumnezeiescului urcuş" (The Ladder of the Divine Ascent), in Filocalia (Philokalia), vol. IX, translation, introduction and notes by Father Dumitru Stăniloae, Bucureşti, Institutul Biblic şi de Misiune al Bisericii Ortodoxe Române, 1980.

\section{Web sources:}

13. https://valeriugafencu.wordpress.com/about/scrisorile-lui-valeriugafencu/ (accessed April 24, 2017)

14. https://www.marturisitorii.ro/2015/02/18/valeriu-gafencu-scrisoarecatre-arsenie-boca-multumesc-din-tot-sufletul-pentru-toate-suferintelesi-umilintele-prin-care-mi-a-fost-dat-sa-trec/ (accessed April 24, 2017). 